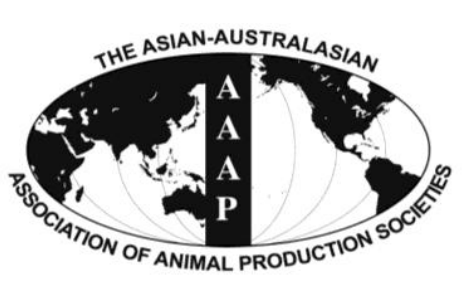

\begin{tabular}{c} 
Open Access \\
Asian Australas. J. Anim. Sci. \\
$\begin{array}{c}\text { Vol. 27, No. } 9 \text { : 1311-1318 September } 2014 \\
\text { http://dx.doi.org/10.5713/ajas.2014.14241 }\end{array}$ \\
\hline www.ajas.info \\
pISSN 101 1-2367 elSSN 1976-5517
\end{tabular}

\title{
Effects of Dietary Supplementation with the Combination of Zeolite and Attapulgite on Growth Performance, Nutrient Digestibility, Secretion of Digestive Enzymes and Intestinal Health in Broiler Chickens
}

\author{
P. Zhou, Y. Q. Tan, L. Zhang, Y. M. Zhou, F. Gao*, and G. H. Zhou \\ College of Animal Science and Technology, Synergetic Innovation Center of Food Safety and Nutrition, \\ Nanjing Agricultural University, Nanjing 210095, China
}

\begin{abstract}
This study was designed to investigate the effects of basal diets supplemented with a clay product consisting of zeolite and attapulgite (ZA) at 1:1 ratio on growth performance, digestibility of feed nutrients, activities of digestive enzymes in small intestine and intestinal health in broiler chickens. In experiment 1, 112 one-day-old male chickens were randomly divided into 2 groups with 8 replicates of 7 chickens each. In experiment 2, 84 one-day-old male chickens were randomly allocated into 2 groups consisting 6 replicates of 7 chickens each. The experimental diets both consisted of a maize-soybean basal control diet supplemented with $0 \%$ or $2 \%$ ZA. The diets were fed from 1 to 42 days of age. The results showed that ZA supplementation could increase body weight gain (BWG) and feed intake (FI), but had no significant effect on feed conversion ratio. The apparent digestibility values of crude protein and gross energy were significantly increased $(\mathrm{p}<0.05)$ by ZA from 14 to $16 \mathrm{~d}$ and 35 to $37 \mathrm{~d}$. Dietary ZA treatment significantly increased $(\mathrm{p}<0.05)$ the activities of amylase, lipase and trypsin in jejunal digesta and the activities of maltase and sucrase in jejunal mucosa on days 21 and 42. The ZA supplementation also significantly increased $(p<0.05)$ the catalase activity, reduced $(p<0.05)$ the malondialdehyde concentration in the jejunal mucosa. In addition, a decrease of serum diamine oxidase activity and an increase $(\mathrm{p}<0.05)$ in concentration of secretory immunoglobulin A in jejunal mucosa were observed in birds treated with ZA on 21 and 42 days. It is concluded that ZA supplementation (2\%) could partially improve the growth performance by increasing BWG and FI. This improvement was achieved through increasing the secretion of digestive enzymes, enhancing the digestibilites of nutrients, promoting intestinal health of broiler chickens. (Key Words: Attapulgite, Broiler, Growth Performance, Intestinal Health, Zeolite)
\end{abstract}

\section{INTRODUCTION}

The silicate minerals such as zeolite, attapulgite, kaolinite, smectite, and sepiolite are found to be effective as non-toxic, cheap, ecologically advantageous and affordable materials based on their high sorption capacity and ionexchange properties (Murray, 2000; Slamova et al., 2011). So they are widely used in many fields of industry, agriculture, environment protection, sanitation, veterinary medicine, and animal nutrition (Mumpton, 1999; Murray, 2000).

Zeolites are crystalline, hydrated aluminosilicates

* Corresponding Author: F. Gao. Tel: +86-25-84399007, Fax: +86-25-84395314, E-mail: gaofeng0629@sina.com

Submitted Mar. 20, 2014; Revised May 6, 2014; Accepted May 20, 2014 consisting of three-dimensional networks of $\mathrm{SiO}_{4}{ }^{4-}$ and $\mathrm{AlO}_{4}{ }^{5-}$ tetrahedra, linked by the sharing of oxygen atoms (Papaioannou et al., 2005). They have the ability to exchange constituent cations without major change of structure and to lose and gain water molecules reversibly. The basis of interest in the biological effects of zeolites concerns one or more of their chemical and physical properties, such as ion exchange ability, molecular sieve and adsorption properties (Papaioannou et al., 2002). It has been reported that zeolites contains lots of major and trace elements which are essential for the growth of aquatic animals, livestock and poultry. These elements are in an ionic state and can be released to these animals for improving their health conditions (Wu et al., 2013a). Moreover, toxins, heavy metals and free radicals could be 
adsorbed and excreted from animal bodies by Zeolites ( $\mathrm{Wu}$ et al., 2013b). There are conflicting reports in the literature of the effects of zeolite on growth performance of broilers. Wu et al. (2013b) reported that the effects of natural zeolite (clinoptilolite) on growth performance of broilers were negligible. However, Ly et al. (2007) reported that the supplementation of zeolite in diets resulted in an increase of body weight and an improvement of the feed conversion ratio (FCR) of the animals. The study of Wu et al. (2013c) showed that zeolite increased the intestinal length and weigh and gut digestive enzyme activity, improved the intestinal morphology. In addition, Saribeyoglu et al. (2011) found that clinoptilolite administration could decrease oxidant activity and increase antioxidant ability after partial hepatectomy.

Attapulgite is a hydrated magnesium aluminum silicate that exists in nature as a fibrillar silicate clay mineral with reactive-OH groups on the surface (Zhang et al., 2013). The major chemical compositions found in attapulgite are: $\mathrm{SiO}_{2}$ $55.03 \%, \mathrm{Al}_{2} \mathrm{O}_{3} 10.24 \%, \mathrm{MgO} 10.49 \%, \mathrm{Fe}_{2} \mathrm{O}_{3} 3.53 \%, \mathrm{H}_{2} \mathrm{O}^{+}$ $10.13 \%$, and $\mathrm{H}_{2} \mathrm{O}^{-} 9.73 \%$ (Lopez-Galindo et al., 2007). Attapulgite has some physical properties including high viscosity, high specific surface area, high absorption and cation exchange ability (Murray, 2000). Therefore it has been mainly used as a food additive to promote growth and health of the pigs and broilers based on its ability to bind toxin and antidiarrheal (Pappas et al., 2010). A previous study reported that attapulgite was beneficial to the intestinal integrity, which improved growth performance in weaned piglets (Zhang et al., 2013). Nutrient digestibilities were also increased by supplementation with the sepiolite, a clay with similar physical properties to attapulgite (Ouhida et al., 2000a; Ouhida et al., 2000b). Because the digesta retention time is increased by clay minerals in the gut of pigs and broilers. Thus, an increased transit time of digesta might allow the digestive enzyme activity to be more effective in the digestion of nutrients (Ouhida et al., 2000a). However, Pappas et al. (2010) reported that attapulgite had no significant effect on growth performance of broilers. Therefore, further researches are needed to determine whether attapulgite has positive effects on growth performance of animals.

It is concluded that zeolite or attapulgite has been widely added to feed for broilers to improve growth performance and health, to reduce toxicant residues and also production costs, based on the description above. But the information about the effects of dietary combination of zeolite and attapulgite (ZA) on growth performance, digestibility of feed nutrients and activities of digestive enzymes is limited. Therefore, the objectives of this study were to evaluate the effects of the combination of ZA on growth performance, digestion, and intestinal health in broiler chickens.

\section{MATERIALS AND METHODS}

\section{Animal management, dietary treatments and sample collection}

Experiment 1: A total of 112, one-day-old healthy male Arbor Acres broiler chickens with an average initial body weight of $46.29 \pm 0.16 \mathrm{~g}$ (mean \pm standard error of the mean [SEM]) were purchased from a commercial hatchery (Hewei, Anhui, China) and randomly allocated into 2 groups consisting of 8 replicates of 7 chickens each. The control group was fed with maize-soybean basal diets and the treatment group was given a basal diet with the addition of $2 \% \mathrm{ZA}$ (the combination of $50 \%$ zeolite and $50 \%$ attapulgite). The zeolite used in this study was provided by Nanjing Institute of Geology and Mineral Resources (Nanjing, China) and the attapulgite was provided by Huaian Shenlite Mining Institute (Huaian, China). All birds were fed with a starter diet from 1 to 21 days followed by a grower diet from 22 to 42 days. The ingredients and nutrient levels of basal diets were formulated to meet the NRC (1994) nutrient requirements of broiler chickens (Table 1). The birds were placed in wire cages in a threelevel battery and housed in a room which was controlled at a brooding temperature of $35^{\circ} \mathrm{C}$ from 1 to 3 days and then gradually decreased to $22^{\circ} \mathrm{C}$ by $1^{\circ} \mathrm{C}$ to per 2 days. Continuous light was maintained during the whole experimental period. Birds were allowed free access to mash diets and water. At 1, 21, and $42 \mathrm{~d}$ of age, birds were weighed and feed intake (FI) was recorded for each replicate as a unit to calculate growth performance including FI, body weight gain (BWG), and FCR. At 21 and $42 \mathrm{~d}$ of age, one bird per replicate was randomly selected and weighed. The blood samples were taken from a wing vein puncture and serum were separated by centrifugation at $3,900 \times \mathrm{g}$ for $15 \mathrm{~min}$ at $4^{\circ} \mathrm{C}$. Serum samples were stored a $-20^{\circ} \mathrm{C}$ for further analysis. At the same time, all birds were killed by cervical dislocation, manual exsanguination. The body cavity was opened and jejunum was removed. The jejunal mucosa were collected from each and stored at $20^{\circ} \mathrm{C}$ for further analysis.

Experiment 2: A total of 84, one-day-old male broiler chickens with an average initial body weight of $39.19 \pm 0.17$ $\mathrm{g}$ (mean \pm SEM) were divided into 2 groups with 6 replicates of 7 chicks each. Diets and management were as same as experiment 1 . The ingredients and nutrient levels of basal diets are shown in Table 1. At 1, 21, and $42 \mathrm{~d}$ of age, chickens were weighed and FI was recorded by cage to calculate growth performance. From 14 to $16 \mathrm{~d}$ and 35 to 37 $\mathrm{d}$ of the experiment, excreta samples were collected from each replicate. The excreta samples were then dried at $60^{\circ} \mathrm{C}$. 
Table 1. Ingredient composition and nutrient levels of the basal diets

\begin{tabular}{|c|c|c|}
\hline Item & 1 to $21 \mathrm{~d}$ & 22 to $42 \mathrm{~d}$ \\
\hline \multicolumn{3}{|l|}{ Ingredient $(\mathrm{g} / \mathrm{kg})$} \\
\hline Maize & 546.5 & 598.5 \\
\hline Soybean meal $(48 \% \mathrm{CP})$ & 327 & 256 \\
\hline Corn gluten meal $(51 \% \mathrm{CP})$ & 45 & 55 \\
\hline Soybean oil & 32 & 43 \\
\hline Limestone & 13 & 14 \\
\hline Dicalcium phosphate & 18 & 15 \\
\hline Lysine-HCl & 2.8 & 2.8 \\
\hline DL-methionine & 1.5 & 1.5 \\
\hline Choline chloride & 1.2 & 1.2 \\
\hline Salt & 3 & 3 \\
\hline Premix $^{1}$ & 10 & 10 \\
\hline Total & 1,000 & 1,000 \\
\hline \multicolumn{3}{|l|}{ Nutrient levels ${ }^{2}$} \\
\hline Metabolisable energy (MJ/kg) & 12.44 & 13.11 \\
\hline Crude protein $(\mathrm{g} / \mathrm{kg})$ & 220.7 & 200.8 \\
\hline Calcium $(\mathrm{g} / \mathrm{kg})$ & 9.9 & 9.35 \\
\hline Total phosphorus (g/kg) & 6.64 & 5.88 \\
\hline Available phosphorus (g/kg) & 4.26 & 3.72 \\
\hline Lysine $(\mathrm{g} / \mathrm{kg})$ & 11.9 & 10.42 \\
\hline Methionine (g/kg) & 5.20 & 4.68 \\
\hline Methionine+cystine $(\mathrm{g} / \mathrm{kg})$ & 8.89 & 8.08 \\
\hline \multicolumn{3}{|c|}{$\begin{array}{l}\text { CP, crude protein. } \\
{ }^{1} \text { Premix provided per kg of diet: vitamin A (transretinyl acetate), } 12,000 \\
\text { IU; vitamin } \mathrm{D}_{3} \text { (cholecalciferol), } 2,500 \mathrm{IU} \text {; vitamin E (DL- } \alpha \text {-tocopheryl } \\
\text { acetate), } 30 \mathrm{mg} \text {; menadione sodium bisulphite, } 2.8 \mathrm{mg} \text {; thiamin } \\
\text { mononitrate, } 2.21 \mathrm{mg} \text {; riboflavin, } 7.8 \mathrm{mg} \text {; nicotinamide, } 40 \mathrm{mg} \text {; calcium } \\
\text { pantothenate, } 10 \mathrm{mg} \text {; pyridoxine hydrochloride, } 4 \mathrm{mg} \text {; biotin, } 0.04 \mathrm{mg} \text {; } \\
\text { folic acid } 1.2 \mathrm{mg} \text {; cyanocobalamin, } 0.015 \mathrm{mg} \text {; iron (from ferrous } \\
\text { sulphate), } 80 \mathrm{mg} \text {; copper (from copper sulphate), } 8 \mathrm{mg} \text {; manganese (from } \\
\text { manganese sulphate), } 110 \mathrm{mg} \text {; zinc (from zinc sulphate), } 65 \mathrm{mg} \text {; iodine } \\
\text { (from calcium iodate), } 0.35 \mathrm{mg} \text {; selenium (from sodium selenite), } 0.3 \\
\text { mg. } \\
{ }^{2} \text { Calculated values. }\end{array}$} \\
\hline
\end{tabular}

Feed samples and excreta were ground for apparent digestibility analysis of crude protein $(\mathrm{CP})$ and gross energy (GE). At 21 and $42 \mathrm{~d}$ of age, one bird per cage was randomly selected and weighed. The serum samples were taken from the wing vein as described in experiment 1 . The birds were killed by exsanguination and the body cavity was opened and the jejunum were removed. The digesta samples from jejunum and jejunal mucosa samples were collected and stored at $-20^{\circ} \mathrm{C}$ for further analysis.

The experimental design and procedures of these two experiments were approved by the Animal Care and Use Committee of Nanjing Agricultural University following the requirements of the Regulations for the Administration of Affairs Concerning Experimental Animals of China.

\section{Apparent digestibility analysis of crude protein and gross energy}

In experiment $2, \mathrm{CP}$ and $\mathrm{GE}$ were analyzed using
AOAC procedures (2000). Acid-insoluble ash (AIA) was determined using the method of Choct and Annison (1992). The calculation of the apparent digestibility of nutrients was as follows:

$$
\begin{aligned}
& \text { Digestibility }(\%) \\
& =100-100 \times(\text { diet AIA \%/excreta AIA \%) } \\
& \quad \times(\text { excreta nutrient \%/diet nutrient \% })
\end{aligned}
$$

\section{Digestive enzyme activities in jejunal digesta and jejunal mucosa tissue}

In experiment 2, the digesta samples from jejunum were carried out from refrigerator and melted. The samples were all diluted with ice-cold phosphate-buffered saline ( $\mathrm{pH} 7.0)$, in the ratio 1:9 (wt/vol) homogenized for $1 \mathrm{~min}$. The homogenate was then centrifuged at $18,000 \times \mathrm{g}$ for $15 \mathrm{~min}$ at $4^{\circ} \mathrm{C}$. The supernatants were divided into small portions for digestive enzyme activity analysis including amylase, lipase, trypsin (Feng et al., 2007). Meanwhile, the jejunal mucosa samples were treated following the same procedures outlined above. And the supernatants were used for anlysing the activity of maltase and sucrase.

The protein concentrations of digesta and jejunal mucosa samples were determined using standard kits (Nanjing Jiancheng Bioengineering Institute, Nanjing, China) according to the instructions of the manufacturer (Wu et al., 2013b). All the enzyme activities were also assayed using standard kits (Nanjing Jiancheng Bioengineering Institute, Nanjing, China) (Wu et al., 2013c). The activity of enzyme was expressed as $\mathrm{U} / \mathrm{mg}$ protein.

\section{Assay of antioxidant indices and secretory immunoglobulin A content in the jejunal mucosa tissue}

In experiment 1 and 2 , the supernatants from the jejunal mucosa samples were obtained as described above and used in this analysis. The enzyme activity of catalase (CAT) and malondialdehyde (MDA) concentration were analyzed using a diagnostic kit (Nanjing Jiancheng Bioengineering Institute, Nanjing, China) according to the manufacturers' instructions (Wu et al., 2013b). Secretory immunoglobulin A (SIgA) content was also determined using a kit (Shanghai Hanyun Biotechnological Ltd., Shanghai, China). The activity of enzyme was expressed as $\mathrm{U} / \mathrm{mg}$ protein. The MDA concentration was expressed as $\mathrm{nmol} / \mathrm{mg}$ protein. The SIgA content was expressed as $\mu \mathrm{g} / \mathrm{mg}$ protein (Tang et al., 2014) .

\section{Serum diamine oxidase activity analysis}

In experiment 1 and 2 , the levels of diamine oxidase (DAO) in the serum were analyzed according to a test kit (Nanjing Jiancheng Bioengineering Institute, Nanjing, China), which were expressed as U/L. 


\section{Statistical analysis}

All experimental data were analyzed using independentsample t-test with SPSS statistical software (Version 16.0 for windows, SPSS Inc., Chicago, USA, 2008). The values were expressed as mean \pm standard error. All statement of significance were considered at $\mathrm{p}<0.05$.

\section{RESULTS}

\section{Growth performance}

The effects of dietary supplementation with ZA on growth performance of broiler chickens in experiment 1 and 2 are shown in Table 2. In experiment 1, from d 1 to 21 , BWG, FI, and FCR were not significantly affected by ZA supplementation. From d 22 to 42 and d 1 to 42, BWG was not significantly increased, but there was a tendency to increase ( $p=0.089$ and $p=0.131$ ). The FI was increased $(\mathrm{p}<0.01)$ and FCR was not affected. In experiment 2 , from d 1 to 21 , BWG was increased ( $\mathrm{p}<0.05)$, ZA supplementation tended to cause an increase in FI $(p=0.081)$, and FCR was not affected. From d 22 to 42, BWG and FI were not significantly affected by ZA supplementation, but there was a tendency to increase $(p=0.092$ and $p=0.109)$, Also ZA supplementation increased BWG and FI $(\mathrm{p}=0.070$ and $\mathrm{p}=$ 0.062 ) from $\mathrm{d} 1$ to 42 . No significant difference was observed in FCR from d 22 to 42 and d 1 to 42.
Table 3. Effects of dietary supplementation with combination of zeolite and attapulgite (ZA) on apparent digestibility of crude protein and gross energy of broiler chickens in experiment 2

\begin{tabular}{lcccc}
\hline Items (\%) & $\begin{array}{c}\text { Period } \\
(\mathrm{d})\end{array}$ & Control & Treatment & $\mathrm{p}$ value \\
\hline Crude protein & $14-16$ & $61.91 \pm 1.20$ & $67.48 \pm 1.17$ & 0.013 \\
& $35-37$ & $61.89 \pm 2.48$ & $67.61 \pm 2.63$ & 0.046 \\
Gross energy & $14-16$ & $72.37 \pm 0.10$ & $76.37 \pm 0.36$ & 0.001 \\
& $35-37$ & $70.67 \pm 0.58$ & $74.34 \pm 0.67$ & 0.003 \\
\hline
\end{tabular}

\section{Apparent digestibility}

The effects of dietary supplementation with ZA on apparent digestibility of CP and GE of broiler chickens in experiment 2 are shown in Table 3. Compared with the control, the apparent digestibility of $\mathrm{CP}$ was increased by ZA supplementation from 14 to $16 \mathrm{~d}(\mathrm{p}<0.05)$ and 35 to 37 $\mathrm{d}(\mathrm{p}<0.05)$. Also an increase of digestibility of GE was observed at both 14 to $16 \mathrm{~d}(\mathrm{p}<0.01)$ and 35 to $37 \mathrm{~d}$ $(\mathrm{p}<0.01)$.

\section{Digestive enzymes activities}

The effects of dietary supplementation with ZA on digestive enzyme activities in jejunal digesta and jejunal mucosa of broiler chickens in experiment 2 are given in Table 4. Compared with the control, amylase activity was increased by ZA supplementation at both $21(\mathrm{p}<0.05)$ and 42 days $(\mathrm{p}<0.05)$ of age. The ZA supplementation also

Table 2. Effects of dietary supplementation with combination of zeolite and attapulgite (ZA) on growth performance of broiler chickens in experiment 1 and 2

\begin{tabular}{|c|c|c|c|c|}
\hline Items & Period $(d)$ & Control & Treatment & $\mathrm{p}$ value \\
\hline \multicolumn{5}{|l|}{ Experiment 1} \\
\hline Initial weight (g/bird) & & $46.25 \pm 0.2$ & $46.33 \pm 0.18$ & 0.748 \\
\hline \multirow[t]{3}{*}{ BWG (g/bird) } & $1-21$ & $713.07 \pm 25.62$ & $692.91 \pm 16.99$ & 0.508 \\
\hline & $22-42$ & $1,636.20 \pm 46.26$ & $1,700.10 \pm 20.88$ & 0.089 \\
\hline & $1-42$ & $2,349.30 \pm 65.18$ & $2,394.00 \pm 14.02$ & 0.131 \\
\hline \multirow[t]{3}{*}{ FI (g/bird) } & $1-21$ & $1,067.22 \pm 23.59$ & $1,058.61 \pm 11.53$ & 0.34 \\
\hline & $22-42$ & $3,153.15 \pm 45.56$ & $3,387.30 \pm 38.56$ & 0.007 \\
\hline & $1-42$ & $4,220.58 \pm 34.45$ & $4,445.70 \pm 37.84$ & 0.008 \\
\hline \multirow[t]{3}{*}{ FCR (feed:gain, g/g) } & $1-21$ & $1.51 \pm 0.05$ & $1.52 \pm 0.02$ & 0.856 \\
\hline & $22-42$ & $1.96 \pm 0.04$ & $2.01 \pm 0.02$ & 0.304 \\
\hline & $1-42$ & $1.81 \pm 0.02$ & $1.85 \pm 0.01$ & 0.150 \\
\hline \multicolumn{5}{|l|}{ Experiment 2} \\
\hline Initial weight (g/bird) & & $39.15 \pm 0.15$ & $39.23 \pm 0.21$ & 0.785 \\
\hline \multirow[t]{3}{*}{ BWG (g/bird) } & $1-21$ & $565.38 \pm 13.27$ & $629.29 \pm 5.43$ & 0.038 \\
\hline & $22-42$ & $1,607.90 \pm 53.78$ & $1,747.30 \pm 57.01$ & 0.092 \\
\hline & $1-42$ & $2,173.30 \pm 43.04$ & $2,376.60 \pm 53.84$ & 0.07 \\
\hline \multirow[t]{3}{*}{ FI (g/bird) } & $1-21$ & $849.85 \pm 12.60$ & $944.05 \pm 29.82$ & 0.081 \\
\hline & $22-42$ & $3,318.90 \pm 91.42$ & $3,535.10 \pm 65.36$ & 0.109 \\
\hline & $1-42$ & $4,064.70 \pm 136.83$ & $4,389.00 \pm 73.19$ & 0.062 \\
\hline \multirow[t]{3}{*}{ FCR (feed:gain, g/g) } & $1-21$ & $1.50 \pm 0.01$ & $1.50 \pm 0.04$ & 0.929 \\
\hline & $22-42$ & $2.06 \pm 0.01$ & $2.03 \pm 0.04$ & 0.411 \\
\hline & $1-42$ & $1.87 \pm 0.02$ & $1.85 \pm 0.03$ & 0.499 \\
\hline
\end{tabular}

BWG, body weight gain; FI, feed intake; FCR, feed conversion ratio. 
Table 4. Effects of dietary supplementation with combination of zeolite and attapulgite (ZA) on digestive enzyme activities in jejunal digesta and jejunal mucosa of broiler chickens in experiment 2

\begin{tabular}{lcccc}
\hline $\begin{array}{c}\text { Items } \\
\text { (U/mg protein) }\end{array}$ & $\begin{array}{c}\text { Age } \\
(\mathrm{d})\end{array}$ & Control & Treatment & $\mathrm{p}$ value \\
\hline Jejunal digesta & & & & \\
Amylase & 21 & $72.34 \pm 4.91$ & $97.05 \pm 7.37$ & 0.024 \\
& 42 & $56.58 \pm 3.23$ & $71.60 \pm 4.16$ & 0.029 \\
Lipase & 21 & $56.62 \pm 2.02$ & $70.82 \pm 2.52$ & 0.002 \\
& 42 & $54.88 \pm 1.19$ & $65.85 \pm 1.72$ & 0.041 \\
Trypsin & 21 & $45.71 \pm 1.79$ & $52.67 \pm 1.64$ & 0.021 \\
& 42 & $44.93 \pm 0.90$ & $49.74 \pm 1.10$ & 0.011 \\
Jejunal mucosa & & & & \\
Maltase & 21 & $15.12 \pm 0.74$ & $22.07 \pm 0.75$ & 0.001 \\
& 42 & $15.54 \pm 0.67$ & $18.74 \pm 0.69$ & 0.011 \\
Sucrase & 21 & $120.16 \pm 2.21$ & $133.75 \pm 3.10$ & 0.015 \\
& 42 & $108.56 \pm 3.46$ & $122.40 \pm 4.05$ & 0.036 \\
\hline
\end{tabular}

increased lipase activity at $21 \quad(\mathrm{p}<0.01)$ and 42 days $(\mathrm{p}<0.05)$ of age. In addition, trypsin activity was increased at both $21(\mathrm{p}<0.05)$ and 42 days $(\mathrm{p}<0.05)$ of age. Moreover, ZA supplementation increased maltase activity at both 21 $(p<0.01)$ and 42 days $(p<0.05)$ of age. Sucrase activity was increased by ZA supplementation at both $21(\mathrm{p}<0.05)$ and 42 days $(\mathrm{p}<0.05)$ of age.

Antioxidant indices, secretory immunoglobulin A content in the jejunal mucosa and serum diamine oxidase activity activity

Table 5 shows the effects of dietary supplementation with ZA on antioxidant capacity, SIgA concentration in the jejunal mucosa tissue and serum DAO activity of broiler chickens in experiments 1 and 2 . In experiment $1, \mathrm{ZA}$ supplementation increased CAT activity at both $21(\mathrm{p}<0.05)$ and 42 days $(\mathrm{p}<0.05)$ of age, reduced the MDA concentrations at $21(\mathrm{p}<0.05)$ and 42 days $(\mathrm{p}<0.05)$ of age. The SIgA concentrations were also increased by ZA supplementation at $21(\mathrm{p}<0.01)$ and 42 days $(\mathrm{p}<0.01)$ of age. In addition, serum DAO activity was decreased $(p<0.01)$ at 42 days of age, but no significant effect was observed at 21 days of age. In experiment 2, the CAT activity was increased at both $21(\mathrm{p}<0.05)$ and 42 days $(\mathrm{p}<0.05)$ of age. MDA concentrations were decreased at $21(\mathrm{p}<0.01)$ and 42 days $(\mathrm{p}<0.05)$ of age. Moreover, dietary ZA treatment tended to cause a decrease of the serum DAO activity at both 21 and 42 days of age.

\section{DISCUSSION}

There are conflicting reports in the literature for the effects of zeolite on growth performance of broilers. Ly et al. (2007) reported that the supplementation of clinoptilolite
Table 5 Effects of dietary supplementation with combination of zeolite and attapulgite (ZA) on antioxidant capacity, SIgA concentration in the jejunal mucosa and serum DAO activity of broiler chickens in experiment 1 and 2

\begin{tabular}{|c|c|c|c|c|}
\hline Items & $\begin{array}{l}\text { Age } \\
\text { (d) }\end{array}$ & Control & Treatment & $\mathrm{p}$ value \\
\hline \multicolumn{5}{|l|}{ Experiment 1} \\
\hline \multirow{2}{*}{$\begin{array}{l}\text { CAT } \\
\text { (U/mg protein) }\end{array}$} & 21 & $0.60 \pm 0.04$ & $0.76 \pm 0.04$ & 0.012 \\
\hline & 42 & $0.75 \pm 0.07$ & $1.25 \pm 0.14$ & 0.035 \\
\hline \multirow{2}{*}{$\begin{array}{l}\text { MDA } \\
\text { (nmol/mg protein) }\end{array}$} & 21 & $0.41 \pm 0.02$ & $0.32 \pm 0.02$ & 0.012 \\
\hline & 42 & $0.45 \pm 0.03$ & $0.35 \pm 0.03$ & 0.026 \\
\hline \multirow{2}{*}{$\begin{array}{l}\text { SIgA } \\
(\mu \mathrm{g} / \mathrm{mg} \text { protein })\end{array}$} & 21 & $2.34 \pm 0.04$ & $3.48 \pm 0.05$ & 0.001 \\
\hline & 42 & $1.83 \pm 0.05$ & $3.02 \pm 0.04$ & 0.001 \\
\hline \multirow{2}{*}{$\begin{array}{l}\mathrm{DAO} \\
(\mathrm{U} / \mathrm{L})\end{array}$} & 21 & $10.45 \pm 1.01$ & $9.31 \pm 1.09$ & 0.462 \\
\hline & 42 & $14.87 \pm 0.79$ & $11.34 \pm 0.61$ & 0.003 \\
\hline \multicolumn{5}{|l|}{ Experiment 2} \\
\hline \multirow{2}{*}{$\begin{array}{l}\text { MDA } \\
\text { (nmol/mg protein) }\end{array}$} & 21 & $0.53 \pm 0.04$ & $0.25 \pm 0.03$ & 0.005 \\
\hline & 42 & $0.65 \pm 0.03$ & $0.54 \pm 0.04$ & 0.043 \\
\hline \multirow{2}{*}{$\begin{array}{l}\text { CAT } \\
\text { (U/mg protein) }\end{array}$} & 21 & $0.53 \pm 0.05$ & $0.98 \pm 0.08$ & 0.043 \\
\hline & 42 & $0.91 \pm 0.04$ & $1.35 \pm 0.07$ & 0.032 \\
\hline \multirow{2}{*}{$\begin{array}{l}\mathrm{DAO} \\
(\mathrm{U} / \mathrm{L})\end{array}$} & 21 & $8.56 \pm 1.34$ & $7.96 \pm 0.64$ & 0.088 \\
\hline & 42 & $15.55 \pm 1.38$ & $13.00 \pm 0.54$ & 0.096 \\
\hline
\end{tabular}

CAT, catalase; MDA, malondialdehyde; SIgA, secretory immunoglobulin A; DAO, diamine oxidase.

in the broiler diet improved BWG and decreased FCR. But some researchers concluded that the effects of dietary supplemented with zeolites on growth performance of broilers were negligible (Wu et al., 2013b,d). Similarly there were opposite reports in the literature of the effects of attapulgite on growth performance of the animals. Previous work by Zhang et al. (2013) showed that adding attapulgite into diets resulted in improving growth performance in weaned piglets. However, Pappas et al. (2010) reported that there was no significant effect of attapulgite supplementation on the body mass and FCR of broilers, which is consistent with the work on sepiolite by Ouhida et al. (2000b). In the present study, no difference was observed on the FCR, but the BWG and FI of birds were increased by ZA during the overall experimental period. Theoretically, a $2 \%$ dilution with a non-digestible ZA should increase FCR. But the current results indicated that broilers fed with $2 \%$ ZA converted feed equally well as broilers on the control diet. This finding could be explained by the significant increase of dietary nutrient digestibility, counteracting the simultaneous effect of dilution of the diet with ZA. Thus the feed costs were deceased by the dietary supplementation with the ZA. Although the exact mechanism of how ZA affect the growth performance in animals is still unclear, the different results may be related to the type, purity, concentration, particle and level of them. The possible mechanisms that ZA can improve the animals' growth can be summarized as: ZA contained a number of macro- and 
microchemical elements (such as minerals) which are indispensable for the growth of animals. These elements are in an ionic state and can be released to the bodies (Slamova et al., 2011; Wu et al., 2013c; Zhang et al., 2013). In addition, they could counteract harmful effects of toxic substances (such as ammonia, hydrogen sulfide, etc.) and reduce bacterial contamination of the gut (e.g., Escherichia coli, Salmonella and dysentery bacillus) due to their high absorption capacity. Then the harmful substances can be eliminated from the body (Slamova et al., 2011; Wu et al., 2013a). Changes in growth performance are also associated with changes in nutrient digestibility and secretion of digestive enzymes (Ouhida et al., 2000b; Wu et al., 2013c).

The jejunum is considered the place where most digestive and absorptive processes occur in small intestine segment (Ouhida et al., 2000a). In the present study, supplementation with ZA could improve apparent digestibility of $\mathrm{CP}$ and $\mathrm{GE}$ and the activities of the digestive enzymes in both jejunal contents and jejunal mucosa of broilers, which were consistent with some previous studies. $\mathrm{Wu}$ et al. (2013c) reported that the supplementation of broiler chicken diets with clinoptilolite exerted beneficial effects in the gut development and significantly increased activities of digestive enzyme including protease, chymotrypsin, trypsin and amylase in the small intestinal contents. Similarly, adding clay minerals into diets improved nutrient digestibility and the secretion of digestive enzymes (Cabezas et al., 1991; Hu et al., 2004). Different mechanisms have been proposed to explain the effect of them on the digestion and productive results of the animals. Clay minerals could increase the intestine viscosity due to the formation of gel, which slows down passage rate of digesta. Thus, an increased transit time of digesta may allow the endogenous enzyme activity to be more effective in the digestion of protein, carbohydrates and fat (Ouhida et al., 2000a), therefore improving the digestibility of nutrients. In addition, the ion-exchange properties of the zeolite may alter the $\mathrm{pH}$ and the ionic composition of gastrointestinal fluids, thereby increasing the secretion of digestive enzymes (Wu et al., 2013c). Moreover, nitrogen is stored by zeolite in the form of ammonium and then be released gradually to the body, thus the digestibility of CP was increased (Maeda and Nose, 1999). In addition, some previous studies showed that villus height was significantly increased by zeolite or attapulgite, which was associated with an increased villus surface area and improved absorptive capacity (Wu et al., 2013c; Zhang et al., 2013).

Apart from nutrient absorption capacity, the intestine is recognized to have barrier functions, which are used to protect the gut from damage. Oxidative stress is strongly implicated in some diseases and is emerging as one of the most important causative agents of aging mutagenesis and tumorigenesis, which could contribute to cell and tissue damage in animal bodies (Wang et al., 2012). The antioxidants may prevent these damages induced by oxidation of lipid and protein (Wu et al., 2013b). Malondialdehyde is the ending product of lipid peroxidation, so the content of MDA is usually used as a biomarker of oxidative stress (Nielsen et al., 1997). The antioxidant enzymes play an important role in cellular defense strategy against oxidative stress, and CAT is one of the most important antioxidant enzymes (Yuan et al., 2011). Our study showed that supplementation with $2 \%$ ZA decreased the concentration of MDA and increased the CAT enzyme activity at both 21 and 42 days. This finding was agreement with the study of Wu et al. (2013b), who concluded that MDA concentration of the liver was decreased and the liver CAT activity was higher when supplemented with $2 \%$ clinoptilolite in poultry diets. Meanwhile, Wang et al. (2012) reported supplementation with zinc-bearing clinoptilolite significantly reduced MDA contents of jejunal mucosa at $21 \mathrm{~d}$. Saribeyoglu et al. (2011) also found that Adding clinoptilolite up to $5 \mathrm{mg} / \mathrm{kg}$ in the diets could significantly decreased plasma and liver tissue MDA levels. These results suggested that the adding of zeolite may support antioxidant system. In addition, it has been reported that the adhesion of attapulgite to heavy metals may inhibit the growth of bacteria (Lavie et al., 1986). So the antioxidant capability of ZA may be attributed to their antibacterial activity, they could adsorb harmful bacterial which respond to oxidative stress, thus improving the antioxidant effects of ZA. Furthermore, the free radicals which contribute to tissue damage were also adsorbed by ZA. The DAO is found exclusively in the villi of the upper small intestine (Reynolds, 1996). The DAO is normally present in very small amounts in the circulation. When intestinal mucosal integrity is damaged, DAO is released into blood. So, plasma DAO may serve as a marker of the injury and integrity of the intestinal mucosa (Wolvekamp and De Bruin, 1994). The present results showed that serum DAO activity of broilers was decreased by ZA at both 21 and 42 days. These results further support earlier reports. The study of Wang et al. (2012) showed that supplementation of zinc-bearing clinoptilolite in basal diet significantly reduced serum DAO activity both at the age of both $7 \mathrm{~d}$ and $21 \mathrm{~d}$. Zhang et al. (2013) reported that dietary supplementation with attapulgite might protect the gut mucosa and reduce blood concentration of DAO. Some mechanisms may contribute to the results in this study. The big specific surface area of attapulgite allows it to become distributed over the surface of the intestinal mucosa to form a protective screen to reduce the gut damage (Zhang et al., 2013). Another possible reason is that the ZA could adsorb toxic substances and bacterial, which are harmful to the 
bodies, and then excrete them from animal bodies (Slamova et al., 2011; Wu et al., 2013a).

The SIgA produced by activated B-cells is the main effector of the mucosal immune system and serve as a first line of defense to protect the gut epithelium from pathogenic microorganisms and noxious compounds (Corthesy, 2013). Also, SIgA promotes the clearance of antigens and pathogenic microorganisms from the intestinal lumen by entrapping them in mucus, blocking their access to epithelial receptors, and facilitating their removal by peristaltic and mucociliary activities (Mantis et al., 2011). In the current study, the content of SIgA in jejunum was significantly increased by ZA at both 21 and 42 days, which was in agreement with the finding of Tang et al. (2014) who concluded that $0.1 \%$ zinc-bearing clinoptilolite supplementation improved the concentration of SIgA in jejunum at $42 \mathrm{~d}$. Based on these results, it is indicating that ZA may enhance the defensive capacity of the mucosal immune system of the jejunum during absorption in broilers.

\section{CONCLUSION}

The results of this study indicate that ZA supplementation (2\%) could partially improve the growth performance by increasing BWG and FI. This improvement was achieved through increasing the secretion of digestive enzymes, enhancing the digestibilites of nutrients, promoting intestinal health of broiler chickens. But the exact molecular mechanism of how ZA affecting the animals is still unknown and further studies are needed.

\section{ACKNOWLEDGMENTS}

This research was funded by the National Science \& Technology Pillar Program during the Twelfth Five-year Plan Period of China (2012BAD28B03), Three Agricultral Projects of Jiangsu province of China (SX(2011)146), and the Fundamental Research Funds for the Central Universities of China (KYZ201222).

\section{REFERENCES}

AOAC. 2000. Official Methods of Analysis, 17th ed. Association of Official Analytical Chemists, Arlington, VA, USA.

Cabezas, M. J., D. Salvador, and J. V. Sinisterra. 1991. Stabilization-activation of pancreatic enzymes adsorbed on to a sepiolite clay. J. Chem. Technol. Biotechnol. 52:265-274.

Choct, M. and G. Annison. 1992. The inhibition of nutrient digestion by wheat pentosans. Br. J. Nutr. 67:123-132.

Corthesy, B. 2013. Role of secretory $\operatorname{IgA}$ in infection and maintenance of homeostasis. Autoimmun. Rev. 12:661-665.

Feng, J., X. Liu, Z. R. Xu, Y. Z. Wang, and J. X. Liu. 2007. Effects of fermented soybean meal on digestive enzyme activities andintestinal morphology in broilers. Poult. Sci. 86:1149-1154.
Hu, C. H., M. S. Xia, Z. R. Xu, and L. Xiong. 2004. Effects of copper-bearing montmorillonite on growth performance and digestive function of growing pigs. Asian Australas. J. Anim. 17:1575-1581.

Lavie, S. and G. Stotzky. 1986. Adhesion of the clay minerals montmorillonite, kaolinite, and attapulgite reduces respiration of Histoplasma capsulatum. Appl. Environ. Microbiol. 51:6573.

Lopez-Galindo, A., C. Viseras, and P. Cerezo. 2007. Compositional, technical and safety specifications of clays to be used as pharmaceutical and cosmetic products. Appl. Clay Sci. 36:51-63.

Ly, J., F. Grageola, C. Lemus, and M. Castro. 2007. Ileal and rectal digestibility of nutrients in diets based on Leucaena (Leucaena leucocephala (Lam.) de Wit) for pigs. Influence of the inclusion of zeolite. J. Anim. Vet. Adv. 6:1371-1376.

Maeda, T. and Y. Nose. 1999. A new antibacterial agent: antibacterial zeolite. Artif. Organs 23:129-130.

Mantis, N. J., N. Rol, and B. Corthesy. 2011. Secretory IgA's complex roles in immunity and mucosal homeostasis in the gut. Mucosal Immunol. 4:603-611.

Mumpton, F. A. 1999. La roca magica: Uses of natural zeolites in agriculture and industry. Proc. e Natl. Acad. Sci. USA. 96:3463-3470.

Murray, H. H. 2000. Traditional and new applications for kaolin, smectite, and palygorskite: A general overview. Appl. Clay Sci. 17:207-221.

National Research Council. 1994. Nutrient Requirements of Poultry. 9th rev. ed. National Academy Press, Washington, DC, USA.

Nielsen, F., B. B. Mikkelsen, J. B. Nielsen, H. R. Andersen, and P. Grandjean. 1997. Plasma malondialdehyde as biomarker for oxidative stress: Reference interval and effects of life-style factors. Clin. Chem. 43:1209-1214.

Ouhida, I., J. F. Perez, J. Gasa, and F. Puchal. 2000a. Enzymes ( $\beta$ glucanase and arabinoxylanase) and/or sepiolite supplementation and the nutritive value of maize-barley-wheat based diets for broiler chickens. Br. Poult. Sci. 41:617-624.

Ouhida, I., J. F. Perez, J. Piedrafita, and J. Gasa. 2000b. The effects of sepiolite in broiler chicken diets of high, medium and low viscosity. Productive performance and nutritive value. Anim. Feed Sci. Technol. 85:183-194.

Papaioannou, D., P. D. Katsoulos, N. Panousis, and H. Karatzias. 2005. The role of natural and synthetic zeolites as feed additives on the prevention and/or the treatment of certain farm animal diseases: A review. Microporous Mesoporous Mater. 84:161-170.

Papaioannou, D. S., S. C. Kyriakis, A. Papasteriadis, N. Roumbies, A. Yannakopoulos, and C. Alexopoulos. 2002. A field study on the effect of in-feed inclusion of a natural zeolite (clinoptilolite) on health status and performance of sows/gilts and their litters. Res. Vet. Sci. 72:51-59.

Pappas, A. C., E. Zoidis, N. Theophilou, G. Zervas, and K. Fegeros. 2010. Effects of palygorskite on broiler performance, feed technological characteristics and litter quality. Appl. Clay Sci. 49:276-280.

Reynolds, J. V. 1996. Gut barrier function in the surgical patients. Br. J. Surg. 83:1668-1669. 
Saribeyoglu, K., E. Aytac, S. Pekmezci, S. Saygili, H. Uzun, G. Ozbay, S. Aydin, and H. O. Seymen. 2011. Effects of clinoptilolite treatment on oxidative stress after partial hepatectomy in rats. Asian J. Surg. 34:153-157.

SPSS Inc. 2008. SPSS 16.0 for Windows. SPSS Inc, Chicago, IL, USA.

Slamova, R., M. Trckova, H. Vondruskova, Z. Zraly, and I. Pavlik. 2011. Clay minerals in animal nutrition. Appl. Clay Sci. 51:395-398

Tang, Z. G., C. Wen, L. C. Wang, T. Wang, and Y. M. Zhou. 2014 Effects of zinc-bearing clinoptilolite on growth performance, cecal microflora and intestinal mucosal function of broiler chickens. Anim. Feed Sci. Technol. 189:98-106.

Wang, L. C., T. T. Zhang, C. Wen, Z. Y. Jiang, T. Wang, and Y. M. Zhou. 2012. Protective effects of zinc-bearing clinoptilolite on broilers challenged with Salmonella pullorum. Poult. Sci. 91:1838-1845.

Wolvekamp, M. C. J. and R. W. F. De Bruin. 1994. Diamine oxidase: an overview of historical, biochemical and functional aspects. Dig. Dis. 12:2-14.
Wu, Q. J., L. C. Wang, Y. M. Zhou, J. F. Zhang, and T. Wang. 2013d. Effects of clinoptilolite and modified clinoptilolite on the growth performance, intestinal microflora, and gut parameters of broilers. Poult. Sci. 92:684-692.

Wu, Q. J., Y. M. Zhou, Y. N. Wu, L. L. Zhang, and T. Wang. 2013a. The effects of natural and modified clinoptilolite on intestinal barrier function and immune response to LPS in broiler chickens. Vet. Immunol. Immunopathol. 153:70-76.

Wu, Q. J., Y. M. Zhou, Y. N. Wu, and T. Wang. 2013c. Intestinal development and function of broiler chickens on diets supplemented with clinoptilolite. Asian Australas. J. Anim. 26:987-994.

Wu, Y., Q. Wu, Y. Zhou, H. Ahmad, and T. Wang. 2013b. Effects of clinoptilolite on growth performance and antioxidant status in broilers. Biol. Trace Elem. Res. 155:228-235.

Yuan, Y. Y., X. Ke, F. J. Chen, P. H. Krogh, and F. Ge. 2011. Decrease in catalase activity of Folsomia candida fed a $B t$ rice diet. Environ. Pollut. 159:3714-3720.

Zhang, J., Y. Lv, C. Tang, and X. Wang. 2013. Effects of dietary supplementation with palygorskite on intestinal integrity in weaned piglets. Appl. Clay Sci. 86:185-189. 